\title{
Peranan triamnicolone acetate terhadap adhesi intraperitoneal pasca laparotomi
}

\author{
${ }^{1}$ Andre Saharui, ${ }^{2}$ Ishak Lahunduitan, ${ }^{3}$ Ferry Kalitouw \\ ${ }^{1}$ PPDS Ilmu Bedah Fakultas Kedokteran Ubiversitas Sam Ratulangi Manado \\ ${ }^{2}$ KSM Ilmu Bedah RSUP Prof. Dr. R. D. Kandou Manado \\ ${ }^{3}$ RSUD Manembo-nembo Bitung \\ Email: andre.saharui@gmail.com
}

\begin{abstract}
Intraperitoneal adhesion could cause mechanical intestinal obstruction, infertility, lengthened duration of operation, and increased intraoperative risk. To date, there is still no certain method to prevent the occurence of intraperitoneal adhesion. Triamcinolone acetate (TA) is a corticosteroid with long half time. Subjects were 16 Wistar rats (Rattus norvegicus) divided into two groups, the control group and the treatment group. Laparotomy and caecal abration were performed on all rats. The treatment group were given $0.1 \mathrm{mg}$ of TA. All rats were terminated on day-14 and intraperitoneal adhesion was evaluated macroscopically and microscopically. The statistical analysis showed that there was a significant difference in the formation of intraperitoneal adhesion between the two groups macroscopically, but not microscopically. Conclusion: Triamnicolone acetate could diminish the formation of intraperitoneal adhesion.
\end{abstract}

Keywords: intraperitoneal adhesion, triamcinolone acetate

\begin{abstract}
Abstrak: Adhesi intraperitoneal dapat menyebabkan obstruksi usus mekanik, infertilitas, memperpanjang waktu operasi, dan meningkatkan risiko terjadinya cidera intraoperatif. Sampai saat ini belum ditemukan metode yang tepat untuk mencegah terjadinya adhesi intraperitoneal. Triamcinolone Acetate (TA) merupakan kortikosteroid dengan waktu paruh yang panjang. Subyek penelitian ialah 16 ekor tikus Wistar (Rattus norvegicus) dibagi dalam 2 kelompok:kelompok kokntrol dan kelompok perlakuan. Dilakukan laparotomi dan abrasi saekum pada semua tikus. Kelompok perlakuan diberikan TA dengan dosis 0,1 mg. Tikus diterminasi pada hari ke-14 dan dinilai derajat adhesi intraperitoneal secara makroskopik dan mikroskopik. Hasil analisis statistik memperlihatkan bahwa pembentukan adhesi intraperitoneal antara kedua kelompok kontrol berbeda bermakna secara makroskopik namun tidak berbeda bermakna secara mikroskopik. Simpulan: Triamnicolone acetate dapat menekan pembentukan adhesi intraperitoneal.
\end{abstract}

Kata kunci: adhesi intraperitoneal, triamcinolone acetate

Adhesi intraperitoneal dapat menyebabkan obstruksi usus mekanik, infertilitas, memperpanjang waktu operasi, dan meningkatkan risiko terjadinya cidera intraoperatif. Sampai saat ini belum ditemukan metode yang tepat untuk mencegah terjadinya adhesi intraperitoneal. ${ }^{1-5}$

Sitokin merupakan senyawa protein yang berperan sebagai perantara pada berbagai respon seluler. Pembentukan adhesi intraperitoneal juga dipengaruhi oleh sitokin. Triamnicolone acetate adalah kortikosteroid sintetik yang terbukti dapat menghambat sitokin proinflamasi dan merangsang pelepasan sitokin antiinflamasi. ${ }^{6-8}$ Walaupun TA telah dipakai untuk mencegah terjadinya fibrosis pada ilmu kedokteran mata ${ }^{6,7}$ namun sampai saat ini belum pernah dipublikasikan hasil penelitian sehubungan dengan efektifitas TA dalam menghambat adhesi intraperitoneal pasca laparotomi. ${ }^{8-11}$ 


\section{METODE PENELITIAN}

Penelitan dilakukan di Laboratorium Patologi Anatomi Fakultas Kedokteran Universitas Sam Ratulangi dan dilaksanakan pada bulan Juli s/d Agustus 2016. Subjek penelitian ialah 16 ekor tikus Wistar (Rattus norvegicus) dengan kriteria sehat dan berat badan 200 gr dibagi dalam dua kelompok, yaitu kelompok kontrol dan kelompok perlakuan.

Pada semua subyek penelitian dilakukan tindakan laparotomi. Anaestesi umum dengan ketamine $25 \mathrm{mg} / \mathrm{kg}$ BB diberikan secara IM dan dilanjutkan dengan tindakan laparotomi paramedian dekstra sepanjang $1 \mathrm{~cm}$ dan manipulasi usus berupa scraping pada serosa saekum sampai tampak bintik perdarahan sepanjang $1 \mathrm{~cm}$.
Pada kelompok kontrol tidak dilakukan instilasi TA sedangkan pada kelompok perlakuan dilakukan instilasi triamcinolone acetate (Flamicort ${ }^{\circledR}$ ) 0,1 mg. Penutupan dinding abdomen dengan jahitan jelujur berbahan polypropylene 4/0. Semua subyek penelitian diberikan perlakuan yang sama dalam kandang.

Pada hari ke-14 dilakukan terminasi dengan insisi mediana dan evaluasi derajat adhesi intraperitoneal secara makroskopik menurut Zuhlke (Tabel 1) dan mikroskopik menurut Yilmaz (Tabel 2). Evaluasi makroskopik dilakukan oleh dokter spesialis bedah dan evaluasi mikroskopik oleh dokter spesialis patologi anatomi. Data diolah secara statistik menggunakan program SPSS versi 22.

Tabel 1. Derajat adhesi makroskopik menurut Zuhlke ${ }^{12}$

\begin{tabular}{|c|c|}
\hline Derajat adhesi & Makrsokopik adhesi \\
\hline Derajat 1 & Adhesi tipis, serat fibrin dapat dilepas secara tumpul \\
\hline Derajat 2 & $\begin{array}{l}\text { Serat adhesi dapat dilepas secara tumpul, sebagian memerlukan } \\
\text { diseksi tajam }\end{array}$ \\
\hline Derajat 3 & Serat adhesi kuat, hanya dapat dilepas secara tajam \\
\hline Derajat 4 & $\begin{array}{l}\text { Adhesi fibrotik sangat kuat seperti kalus, cidera organ sulit } \\
\text { dihindari }\end{array}$ \\
\hline
\end{tabular}

Tabel 2. Derajat adhesi mikroskopik menurut Yilmaz ${ }^{13}$

\begin{tabular}{ll}
\hline Derajat adhesi & Mikrsokopik adhesi \\
\hline Derajat 1 & Jaringan fibrosis ringan yang tipis \\
Derajat 2 & Fibrosis luas dengan vaskularisasi \\
Derajat 3 & $\begin{array}{l}\text { Fibrosis luas yang dibentuk oleh jaringan } \\
\text { kolagen tebal }\end{array}$ \\
\hline
\end{tabular}

\section{HASIL PENELITIAN}

Hasil evaluasi derajat makroskopik dikelompokkan berdasarkan kelompok perlakuan. Secara keseluruhan, angka kejadian adhesi intraperitoneal macroskopik sebesar $68,75 \%$ sedangkan yang tidak terjadi adhesi sebesar 31,25\%. Angka kejadian adhesi intraperitoneal secara mikroskopik sebesar $68,75 \%$ sedangkan yang tidak terjadi adhesi sebesar 31,25\%. Selama melakukan penelitian, tidak ada tikus yang mati.

Hasil uji Mann-Whitney terhadap perbedaan derajat adhesi intraperitoneal secara makroskopik antara kelompok kontrol dan kelompok perlakuan, mendapatkan nilai $P<0,05$ yang berarti terdapat perbedaan bermakna antara kedua kelompok dalam pembentukan adhesi intraperitoneal secara makroskopik (Gambar 1).

Hasil uji Mann-Whitney terhadap perbedaan derajat adhesi intraperitoneal secara mikroskopik antara kelompok kontrol dan perlakuan mendapatkan nilai $P$ $>0,05$ yang berarti tidak terdapat perbedaan bermakna antara kedua kelompok dalam pembentukan adhesi intraperitoneal secara mikroskopik (Gambar 2). 


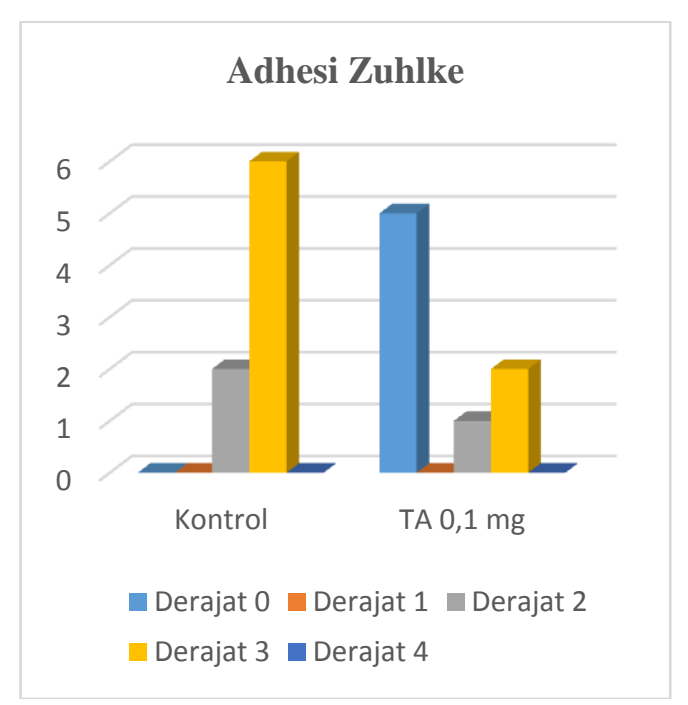

Gambar 1. Derajat adhesi makroskopik menurut Zuhlke pada tiap kelompok

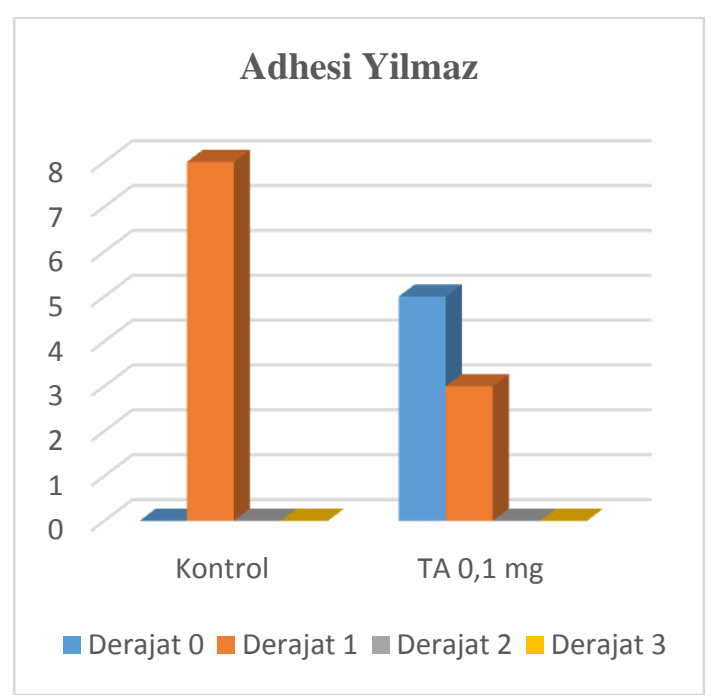

Gambar 2. Derajat adhesi mikroskopik menurut Yilmaz pada tiap kelompok
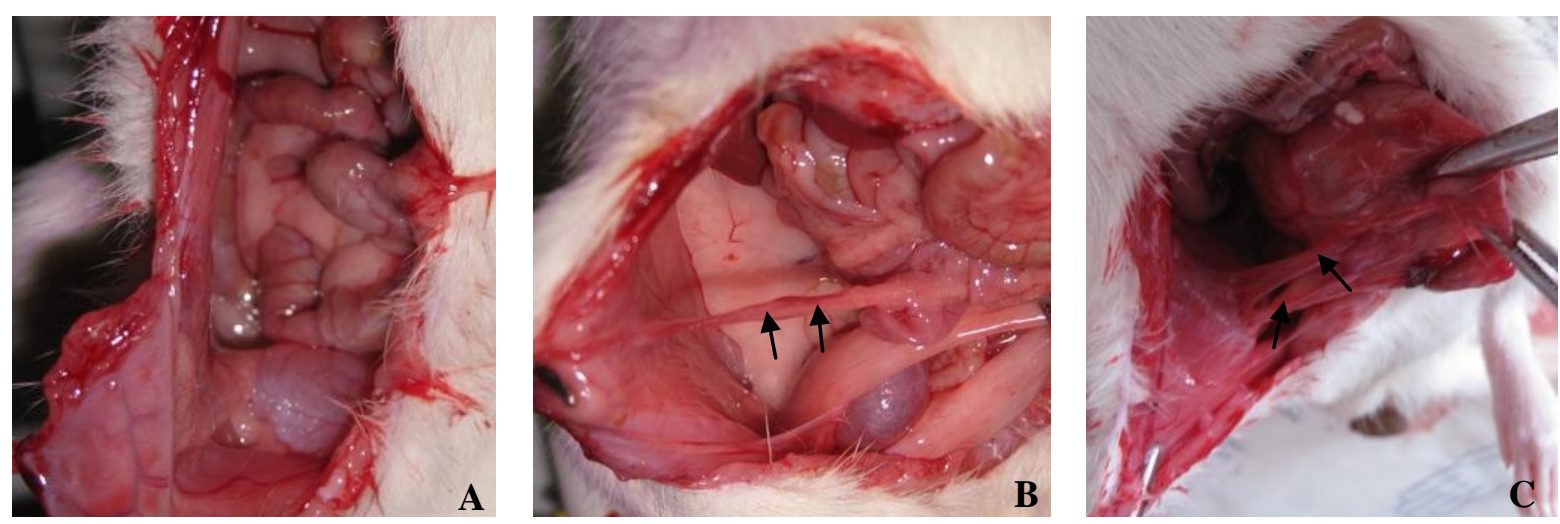

Gambar 3. Gambaran makroskopik adhesi intraperitoneal. A, Tidak terjadi adhesi intraperitoneal pada tikus perlakuan TA $0,1 \mathrm{mg}$; B, Adhesi intraperitoneal derajat 2 pada tikus perlakuan TA 0,1 $\mathrm{mg}$; C, Adhesi intraperitoneal derajat 3 pada tikus kelompok kontrol (Panah hitam menunjukkan adhesi)
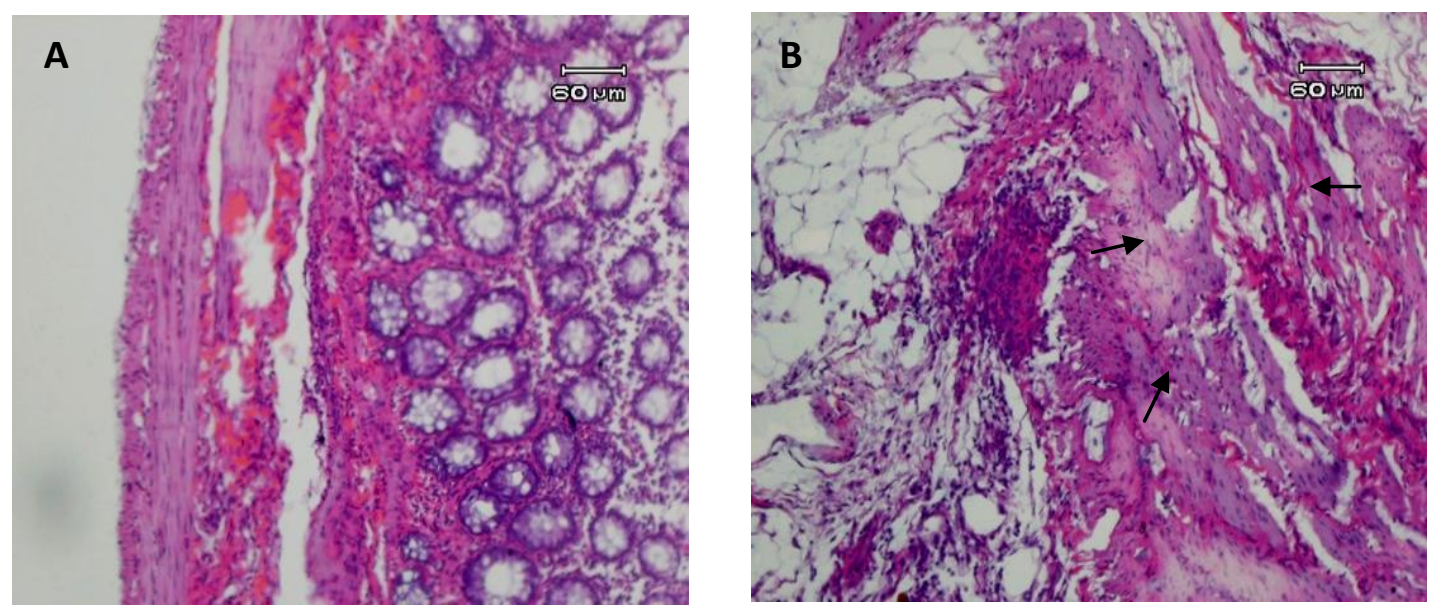

Gambar 4. Gambaran mikroskopik adhesi intraperitoneal. A, Tidak terjadi adhesi intraperitoneal pada tikus perlakuan TA $0,1 \mathrm{mg}$; B, Adhesi intraperitoneal derajat 1 pada tikus kontrol (panah hitam) 


\section{BAHASAN}

Adhesi merupakan suatu proses fisiologik pada penyembuhan peritoneum namun adhesi intraperitoneal dapat menimbulkan berbagai komplikasi. Adhesi intraperitoneal merupakan komplikasi pascapalarotomi dengan tingkat morbiditas yang tinggi. ${ }^{11-16}$

Triamcinolone acetate banyak digunakan sebagai anti fibrosis tetapi belum pernah diuji cobakan aplikasinya sebagai antiadhesi. Dari segi harga, triamcinolone acetate memiliki harga yang cukup terjangkau bila dibandingkan dengan preparat anti adhesi yang sering digunakan dewasa ini. Dosis terapeutik triamcinolone acetate dengan pemberian perenteral pada manusia ialah $0,11-1,6 \mathrm{mg} / \mathrm{kgBB} /$ hari. $^{8}$

Pada analisis data setiap hewan coba tikus baik dari kelompok perlakuan maupun kontrol, didapatkan bahwa kejadian adhesi intraperitoneal berbeda secara makroskopik tetapi distribusinya sama yaitu adhesi terbanyak terjadi pada kelompok kontrol sedangkan pada kelompok perlakuan angka kejadian adhesi intraperitoneal lebih rendah karena dilakukan upaya pemberian preparat anti adhesi (TA). Walaupun demikian, hasil penelitian menunjukkan tidak terdapat anti adhesi ideal yang dapat menghambat kejadian adhesi intraperitoneal sampai $100 \%$.

Hasil uji statistik memperlihatkan bahwa triamcinolone acetate dapat menekan angka kejadian adhesi intraperitoneal secara makroskopik (Zuhlke) dan mikroskopik (Yilmaz) dibandingkan dengan kelompok kontrol. Hal ini terjadi karena triamcinolone acetate berperan dalam menekan reaksi fibrosis dan merangsang terjadinya fibrinolisis. . $^{8} 17,18$

Hasil uji statistik memperlihatkan bahwa kelompok perlakuan TA $0,1 \mathrm{mg}(0,5$ $\mathrm{mg} / \mathrm{kgBB}$ ) tidak berbeda bermakna dibandingkan kelompok kontrol secara mikroskopik. Hal ini mungkin disebabkan karena TA diberikan dengan dosis minimal terapi sehingga kejadian adhesi intraperitoneal yang dipengaruhi oleh multifaktor tidak dapat dihambat secara optimal. $2,4,8,17,19,20$

\section{SIMPULAN}

Dari hasil penelitian dan bahasan dapat disimpulkan bahwa triamcinolone acetate dapat menekan pembentukan adhesi intraperitoneal secara bermakna dan aman bila diberikan sesuai dengan batas dosis terapetik.

\section{DAFTAR PUSTAKA}

1. Al-Musawi, Thompson J. Adhesion prevention: state of the art. Gynaecol Endosc 2001:10:123-30.

2. Arung W, Meurisse M, Detry O. Pathophysiology and prevention of postoperative peritoneal adhesions. World J Gastroenterol. 2011;17:4545-53.

3. Kutlay J, Ozer Y, Isik B, Kargici H. Comparative effectiveness of several agents for preventing postoperative adhesions. World J Surg. 2004;28:662-5.

4. Ward B, Panitch A. Abdominal adhesions: current and novel therapies. J Surg Res. 2009;165;91-111.

5. Basoglu M, Kiziltunc A, Ackay F, Keles S, Gundogdu C, O'ren D. Tumor Necrosis Factor- $\alpha$ and Interleukin- 6 in Peritoneal Adhesion Formation. Tr J Med Sci. 1998;28;253-358

6. Ebrahem Q, Minamoto A, Hoppe G, AnadApte B, Sears JE. Triamcinolone acetonide inhibits IL-6 and VEGFinduced angiogenesis downstream of the IL-6 and VEGF receptors. IOVS. 2006;47(11):4935-41.

7. Xu JH, Liu ZL, Li RX, Wei K, Wei Z, Liu $\mathbf{N N}$, et al. The inhibitory effect of triamcinolone acetonide on the proliferation of monkey choroid-retinal endothelial cells in hypoxia condition. Int J Ophthalmol. 2008;1:38-41.

8. Doggrell SA. Triamcinolone. J Drug Eval. 2003;1;255-91.

9. Zuhlke HV, Lorentz EM, Straub EM, Savvas V. Pathophysiology and classification of adhesion. Langenbecks Arch Chir Suppl II Verh Dtsch Ges Chir. 1990;1009-16.

10. Yilmaz HG, Tacyildiz IH, Keles C, Gedik E, Kilinc N. Micronized purified flavonoid fraction may prevent formulation of intraperitoneal adhesion in rats. Fertilsteril 2005;84(suppl 2): 10838.

11. Kamel R. Prevention of postoperative 
peritoneal adhesion. Eur $\mathrm{J}$ Obstet Gynecol Reprod Biol. 2010:150:111-8.

12. Cheong YC, Laird SM, Li TC, Shelton JB, Ledger WL, Cooke ID. Peritoneal healing and adhesion formation/ reformation. Hum Reprod Update. 2001;7:556-66.

13. Hellebrekers BWJ, Kooistra T Pathogenesis of postoperative adhesion formation. Br J Surg. 2011;8: 1503-16.

14. Herrich S, Mutsaers S, Ozua P, Sulaiman $\mathbf{H}$, Omer A, Boulos P, et al. Human peritoneal adhesions are highly cellular, innervated and vascularized. $\mathrm{J}$ Pathol Early View. 2000:192(1):67-72

15. Cahill R, Redmond HP. Cytokine orchestration in post-operative peritoneal adhesion formation. World J Gastroenterol. 2008;14(31);4861-6.

16. Guvenal T, Cetin A, Ozdemir H, Yanar O, Kaya T. Prevention of postoperative adhesion formation in rat uterine horn model by nimesulide; a selective COX-2 inhibitor. Hum Reprod. 2001;16:1732.

17. French K, Pollitt C, Pass $M$. Pharmacokinetics and metabolic effects of triamcinolone acetonide and their possible relationships to glucocorticoidinduced laminitis in horses. J Vet Pharmacology Ther. 2000;23:287-92.

18. Kupperman B. Underlaying basis and goals of macular edema therapy. John Hopkins Advanced Studies in Opthalmology. $2007 ; 4 ; 7$.

19. Beck D. Intra-abdominal adhesions: Understanding this difficult complication of abdominal surgery. The Phoenix. 2009:6:68-70.

20. Matsuda S, Gomi F, Oshima Y, Tohyama M, Tano Y. Vascular endothelial growth factor reduced and connective tissue growth factor induced by triamcinolone in ARPE19 cells under oxidative stress. Invest Ophthalmol Visual Sci. 2005;46(3): 1062-6. 